\title{
6.10 Лекційне забезпечення навчального процесу на кафедрах факультету підвищення кваліфікації викладачів Національного Університету Охорони Здоров'я України Імені П.Л. Шупика
}

Вступ. Досягнення сучасної медичної науки ставлять перед закладами вищої освіти цілу низку завдань, одним із яких $є$ збільшення кількості інформації, якою повинен оволодіти спеціаліст, чи лікар, який проходить навчання [465]. Без підвищення рівня фундаментальної підготовки наразі неможливо досягти головної мети перебудови медичної освіти - суттєвого покращання якості підготовки спеціалістів-медиків. Рівень викладання навчального матеріалу має забезпечити опанування слухачами закладів вищої освіти великого за обсягом інформації матеріалу за одиницю часу та іiі використання в процесі як навчання, так і в подальшій практичній діяльності.

Чільне місце у теоретичній підготовці лікарів в закладах вищої освіти посідає лекція. Нові тенденції, що намітились в реформуванні системи підготовки лікарів, обумовлюють необхідність впровадження в навчальний процес нових форм і методів навчання, які мають сприяти його інтенсифікації, стимулювати розумову діяльність студентів і лікарів-слухачів $[466,467]$. Сучасна лекція покликана озброїти слухачів знаннями методологічних основ певної клінічної дисципліни, ознайомити їх 3 основними етапами становлення i розвитку теоретичних концепцій, i, нарешті, тільки на лекції студент чи лікарслухач може сформулювати чітке уявлення про сучасний стан тієї чи іншої проблеми. 3 огляду на надзвичайно високий темп розвитку сучасної медичної науки, ні один із самих сучасних підручників, посібників чи монографія аналогічного завдання вирішити не зможуть. Не зможуть замінити лекцію навіть найкращим методологічним чином організовані семінарські чи практичні заняття.

Основна частина. Одною із основних форм організації систематичних навчальних занять при викладанні як клінічних, так і теоретичних дисциплін у закладах вищої освіти є лекція, як носій необхідної інформації з того чи іншого розділу відповідної дисципліни. Крім того, лекція $\epsilon$ незамінною для 
систематизації та структурування всього обсягу знань, отриманих слухачами 3 кожної конкретної навчальної дисципліни.

Згідно Вікіпедії (вільна енциклопедія) подано наступне визначення лекції: «лекція - це основна форма проведення навчальних занять, призначених для подальшого засвоєння теоретичного матеріалу».

Залежно від мети та форми або методів викладу навчального матеріалу лекції поділяються на вступні, навчальні, інформаційні, оглядові, проблемні, відкриті, підсумкові, комплексні, клінічні тощо.

Основною дидактичною метою лекції є забезпечення орієнтовної основи для засвоєння слухачами навчального матеріалу. Доцільно відмітити, що наявність певної частини самостійної роботи слухачів на сьогодні є вимогою до організації навчального процесу у вищій школі.

Кожна лекція виконує ряд функцій: інформаційну, стимулюючу, виховну, розвиваючу, методологічну, пояснювальну та сприяє активізації процесу мислення i уваги слухачів; створює умови для самостійного вивчення навчального матеріалу за підручниками, посібниками, керівництвами; формує мотивацію для роботи в пошукових мережах INTERNET.

Лекція повинна мати відповідну структуру і містити такі елементи як: вступ, у якому формулюється мотивація навчання, мета лекції та основні питання даної теми; виклад основного матеріалу; висновки, які надають можливість систематизувати навчальний матеріал і виділити основну ідею; відповіді на запитання слухачів та рекомендації щодо поглиблення самостійного вивчення теми.

Вузловими критеріями оцінки лекції є: зміст, методика, керівництво роботою слухачів, лекторські дані та результативність лекції. На ефективність лекції позитивно в пливають і деякі чинники довкілля (оптимальне освітлення, відсутність сторонніх звуків, чисте повітря аудиторії, зручні робочі місця, добра акустика, естетичне оформлення аудиторії тощо) та мистецтво лектора (відмінне знання предмету, бажання бути добрим лектором, культура мови, вміння логічно викладати свої думки, наполеглива праця з підготовки кожної лекції, практика і 
тренування, зовнішній вигляд, вміння налагодити контакт 3 аудиторією, педагогічний такт тощо). При підготовці до лекції лектору необхідно чітко визначити цілі і задачі лекції, дати назву у відповідності з навчальним планом і програмою предмета чи курсу, скласти план лекції, а потім конспект з вказівкою переліку літератури i необхідних цифрових даних, підготувати відповідні ілюстративні матеріали тощо.

При читанні лекції викладач зобов’язаний дотримуватись зовнішнього і внутрішнього регламенту занять (початок, кінець, розділи лекції), чіткої структури та виконання плану лекції, доступності та пояснення нових термінів і понять, виділення головних думок і висновків, підведення підсумків в кінці окремих питань та по всій лекції, використовувати технічні засоби навчання і ін. До читання кожного виду лекції необхідно підходити індивідуально, з творчою наснагою, оскільки лекції суттєво відрізняються між собою за метою, змістом та інформацією. Наприклад, вступна лекція знайомить слухачів з метою циклу (курсу), його місцем у системі навчальних дисциплін. Вступна лекція висуває та обгрунтовує основні методологічні позиції курсу, визначає предмет і методи дисципліни, що вивчається. Дуже важливим для вступної лекції $є$ зв’язок теоретичного матеріалу 3 практичними аспектами роботи лікаря. Під час вступної лекції викладач має можливість охарактеризувати підручник та навчальний посібник, які пропонуються для опрацювання; ознайомити слухачів 3 обов'язковою (рекомендованою) літературою. Таким чином, така лекція орієнтує лікарів на подальшу самостійну роботу та знайомить 3 методикою засвоєння циклу.

Тематична лекція - найбільш поширений вид лекції для вищої школи, у якій всебічно розкривається те чи інше питання, висвітлюються головні аспекти наукової проблеми, взаємозв’язок між різними розділами та темами курсу.

Оглядова лекція - передбачає систематичне узагальнення та аналіз головних проблем курсу. Як правило, аналіз має бути пов’язаний з практичною роботою слухачів. Таку лекцію рекомендується проводити у кінці вивчення декількох тем, оскільки вона є узагальнюючою. Але оглядова лекція може передбачати також 
загальне ознайомлення з навчальним матеріалом, який не планується для більш детального вивчення. Крім того, такі лекції дуже важливі для активізації самостійної роботи слухачів з метою опанування певних тем.

Квінтесенцією курсу є оглядово-повторювальна лекція, яка читається у кінці курсу та відображає всі положення, які складають науково-понятійну основу курсу.

Інформаційна лекція - надає головну інформацію з теми відповідно до навчального плану та програми.

Підсумкова (або заключна) лекція - завершує лекційний курс, систематизує одержані знання, підводить підсумки прочитаного курсу.

Слід зазначити, що у ВМНЗ післядипломної освіти крім вищенаведеної класифікації можуть використовуватись і інші види лекцій, які поділяють залежно від методів викладання навчального матеріалу.

Монолекція - $є$ начитуванням навчального матеріалу.

Проблемна лекиія - найбільш складний вид лекції, який вимагає від викладача глибокого володіння матеріалом, вміння створити проблемну ситуацію. При цьому теоретичний матеріал подається у вигляді проблемної задачі, що має певні протиріччя, які викриваються і розв'язуються разом зі слухачами.

Лекція-візуалізація. Така лекція є носієм усної інформації, перетвореної у візуальну форму. Можуть бути використані такі форми наочності, як: символічні (таблиці, схеми), образотворчі (фото, малюнки, слайди), натуральні (реактиви, препарати, апаратура і ін.). Загалом читання даної лекції - це розгорнутий коментар підготовлених візуальних матеріалів.

Клінічна лекція. Особливістю даного різновиду лекцій є іï структура. Проведення іiі потребує певної організації як навчального, так і лікувального процесу. Асистент лектора напередодні вивчає історії хвороб пацієнтів у базовому відділенні, вибирає, на його погляд, історію із класичним перебігом хвороби і готує коротку презентацію з даного клінічного випадку. Із згоди пацієнта можлива його демонстрація під час доповіді. Звертають увагу на 
патогномонічні прояви хвороби, за участю лектора проводять огляд хворого, акцентуючи увагу на певних симптомах. Аналізують дані лабораторних, інструментальних і спеціальних досліджень. Завершують презентацію формулюванням діагнозу згідно сучасної класифікації захворювання. Дана частина лекції не має перевищувати 15 хвилин. Далі лектор переходить до викладення етіології, патогенезу, клініки, класифікації, діагностики та лікування захворювання. Звертають особливу увагу на особливі клінічні варіанти його перебігу. Під час проведення клінічної лекції можливе інтерактивне опитування слухачів.

Майстер-клас - уроком це назвати примітивно. Після такого майстер-класу слухач сам зможе виконувати те чи інше.

Лекція - прес-конференціiя також достатньо складний вид лекції, що потребує від викладача високого професійного рівня, вміння швидко аналізувати та узагальнювати дані, які надходять. Під час такої лекції викладач називає іiі тему та просить слухачів надати письмові запитання з теми. Викладач впродовж 3 - 5 хвилин отримує питання стосовно змісту та починає лекцію. При цьому лекція не повинна виглядати як відповіді на запитання, а бути повноцінним текстом, в процесі викладання якого даються відповіді на запитання, що надійшли. Така лекція цікава тим, що вона надає можливість отримати зріз знань слухачів.

Лекція вдвох - цей вид лекції є розвитком проблемного викладання теми навчального курсу у формі діалогу двох викладачів. Але необхідно пам'ятати, що така лекція вимагає грунтовної підготовки викладачів для сумісного вирішення проблеми, вміння активізувати розмову з аудиторією. Необхідно, щоб слухачі були залучені до дискусії, задавали питання, наводили випадки із практичної діяльності, висловлювали власну думку. Важливою частиною лекції є відповіді на запитання слухачів.

Як правило, на цей елемент лекції відводиться мало часу, але нерідко питання після прочитаної лекції перетворюються в окремий вид роботи лектора. Виходячи з цього виділяють наступні активні форми лекцій: 
Лекиія-брифінг - складається 3 двох частин: короткого повідомлення лектора (до 20 хвилин) і відповідей на запитання слухачів (до 60 хвилин). Дуже важливим є зміст та форма повідомлення, тому викладач повинен ретельно підготуватись до нього. Принципова методична структура лекції-брифінгу: повідомлення лектора $\rightarrow$ запитання слухачів $\rightarrow$ відповіді лектора.

Лекиія-бесіда будується по-іншому. Якщо лекція-брифінг не передбачає виступів слухачів, а тільки запитання, то при цьому виді лекції допускаються виступи слухачів, викладення їх позиції, обмін досвідом т. ін. Таким чином, методична специфіка лекції-бесіди в тому, що викладач надає певну інформацію, ставить питання слухачам, щоб почути їх висловлювання, направляє діалог у потрібне русло.

Цікавим видом лекції є лекція-дисnуm. Вона також має короткий вступ на початку, а потім перетворюється у полемічну бесіду. Функції лектора передбачають організацію лекції таким чином, щоб виникали зіткнення думок, аналіз проблем, які розглядаються. Методична особливість лекції такого типу полягає в тому, що викладач повинен не тільки вміти вести бесіду, відповідати на запитання, але й мати навички організації диспуту та керування ним.

Існує ще один вид лекції - лекція-анкета. Викладач складає анкету опитувач з 20 - 25 питань за темою лекції. На початку лекції, отримавши анкету, слухачі під керівництвом лектора видаляють ті питання, які не викликають складностей. Питання, які залишились, ранжирують за ступенем складності, актуальності, тематикою, і таким чином складають план лекції. 3 методичної точки зору така лекція досить складна як на етапі підготовки, так і на етапі проведення. Від лектора вимагаються значні зусилля при складанні анкет, ерудованість, вміння аналітично мислити.

Практикується також бінарна лекиіiя чи лекиія-дует. Вона читається одночасно двома викладачами. Важливою умовою успішного проведення такої лекції є розподіл навчального матеріалу та попередня підготовка лекторів. Крім того, від викладачів вимагається вміння співпрацювати та імпровізувати. Не менш важливим є також глибока професійна підготовка викладачів. 
В лекційній практиці також описується ситуація під назвою «круглий стіл». В цьому випадку два або більше лектори розглядають одну загальну тему в одній аудиторії. Викладачі повинні і вести бесіду зі слухачами, і відповідати на їх питання. Вважається, що такий вид лекції максимально демократизує взаємовідносини лекторів та слухачів при обговоренні будь-якої проблеми.

У ряді випадків читаються також лекиійні спецкурси. Як правило, вони виходять за рамки навчальної програми, поглиблюють знання, отримані під час засвоєння програми. Завдяки лекційному спецкурсу слухачі знайомляться 3 певною науковою тематикою, науково-дослідною роботою кафедри тощо.

Висновки. У структурі всіх лекцій, що присвячені певній дисципліні чи вивченню певного курсу, для забезпечення підвищення якості навчального процесу, переважати мають лекції проблемного характеру, комплексні та клінічні лекції. Сучасна лекція має бути добре ілюстрованою, вона не повинна мати описовий характер. Для більшої інформативності мають використовуватися слайди, навчальні фільми, відеотехніка, а клінічні лекції мають ілюстроватися клінічними розборами і демонструванням тематичних хворих. Однак широке впровадження та використання технічних засобів навчання у навчальний процес не повинно замінювати живе слово педагога, применшувати значення особистості викладача-лектора. Сучасна підготовка висококваліфікованих лікарів передбачає оволодіння ними фундаментальними теоретичними знаннями, а також практичними вміннями та навичками. Професіоналізм викладача вищого начального медичного закладу, без сумніву, включає володіння предметом викладання та уміннями і навичками, що базуються на практичному досвіді. Саме професіоналізм лектора, як фахівця і як педагога, $\epsilon$ запорукою забезпечення підготовки висококваліфікованого та всебічно освіченого лікаря. Звичайно, з впровадженням дистанційного навчання, суттєво зміниться методологія проведення занять із слухачами, але живе слово лектора завжди буде залишатися запорукою розвитку клінічного та наукового мислення у слухачів. Лекція $є$ незамінним елементом у функції систематизації і структурі 
всього масиву знань з будь-якої дисципліни та служить головною ланкою дидактичного циклу навчання.

Проведення означених різновидів лекцій широко практикується у забезпеченні навчального процесу на кафедрах факультету підвищення кваліфікації викладачів Національного університету охорони здоров’я України імені П. Л. Шупика. 